\title{
The Roles of Health Awareness and Knowledge in Medical Takaful Purchase Intention
}

\author{
Muhammad Zarunnaim Haji Wahab* \\ Asma Mohd Tajuddin \\ Islamic Business School, Universiti Utara Malaysia, Malaysia \\ *Corresponding author: zarunnaim@yahoo.com
}

A R T I C L E I N F O

Article history:

Received 18 April 2019

Revised form 24 October 2019

Accepted 3 November 2019

Published 6 January 2020

Keywords:

Medical takaful, customer's intention, health awareness, knowledge, public sector officers.

JEL Code: M 3, M 1, I1

\section{A B S T R A C T}

The present study aims to examine the factors of health awareness and knowledge that influence customers' intention to use medical takaful coverage among the public sector officers in northern Malaysia. A quantitative research methodology was adopted to answer the objectives progressively. In the current research, data from 313 respondents were collected via questionnaires from three different organisations, namely the police department, the fire and rescue firefighter department, and the education department. Moreover, the data analysis was performed using SPSS version 22. The analysis revealed a significant and positive relationship between health awareness and knowledge and the customers' intention to purchase medical takaful. Apart from that, the results also indicated that only health awareness has a significant influence on the intention with the strongest impact. On the other hand, the knowledge variable had no significant influence on customers' intention to use medical 


\begin{tabular}{l} 
takaful coverage among the \\
respondents. A number of important \\
limitations need to be considered in \\
the present study which will be further \\
explained in the conclusion section. \\
Furthermore, the current research \\
provides some major implications. \\
First, on behalf of the takaful industry, \\
the findings of the present study \\
encourage the takaful operators, \\
marketing teams, staffs, and agents \\
to improve their performance by \\
increasing their efficiency, creativity, \\
innovation, and knowledge of \\
product features in developing a good \\
impression among potential customers. \\
Second, on behalf of the public sector \\
officers, the results of the study show \\
the important need to enhance the \\
customers' intention to use medical \\
takaful coverage. Third, the suitability \\
of factors such as health awareness, \\
knowledge and customers' intention \\
in the previous theory and literature \\
on takaful industry has been proven \\
in the current research. This study \\
helps the marketing team of the takaful \\
operators to formulate marketing \\
strategies that can attract potential \\
customers to participate in the medical \\
takaful coverage, especially among the \\
public sector officers. \\
\hline
\end{tabular}

\section{Introduction}

The basic concept of takaful is to protect humans from risks, while also promoting the element of brotherhood, solidarity, and mutual assistance among the members of a society (Marhanum et al., 2013). The application of takaful is based on the Shari'ah-compliant product which is in line with the Al-Quran and As-Sunnah. More importantly, several verses from the Quran such as verse 2 of Surah al-Ma'idah and verse 201 of Surah al-Baqarah acknowledge the validity of the elements applied in takaful. 
According to Hamid et al. (2011) the concepts of takaful and conventional insurance are different. Takaful is a concept developed based on three principles, namely mutual responsibility, cooperation with each other, and protecting one another from any kind of difficulties, disasters, and other misfortunes. Regarding this matter, it should be understood that the contribution fund is based on the concept of tabarru'. Most Islamic jurists agree that the operation of the conventional insurance contradicts the rules and requirements of the shari'ah. A clear explanation for this matter is that the operational activities of conventional insurance evidently involve the elements of uncertainty (gharar), gambling (maysir), and interests (riba) (Hamid et al., 2011; Munawar, 2013).

In the takaful industry, the assessment of the customers' intention is important for the purpose of enticing them to participate in takaful products. Accordingly, it is necessary to examine customers' purchasing attitude and behavior in order to fulfil customers' intention and satisfaction. Regarding this matter, Gillmore et al. (2002) and Abubakar et al. (2017) define intention as a relationship between behaviors and attitudes within a human action. Hence, intention can be utilized to predict how individuals behave based on their preexisting attitudes and behavioral intentions in purchasing an item. As a result, customers' satisfaction can be achieved if the decision is accurately made within their intention.

A factor that influences customers' intention is health awareness. A study by Benjamin et al. (2014) highlighted the importance of health protection for individuals who have to bear the high cost of medical expenses in the future. Indeed, Kumanyika et al. (2000) found that only a few succeeded in maintaining a healthy lifestyle even though they initially had the intention of doing so. Webb and Sheeran (2006) indicated that good intentions influence the actual behavior to pursue healthy behavior in an attempt to ensure the best actual goal-oriented behavior for public health awareness.

In Malaysia, public health care services have been experiencing establishment pressures due to the increasing demand and limited available resources. Current services have almost provided full insurance to the overall population and all civil servants. Subsequently, this causes health care services and patients to suffer from overcrowding, understaffing, lack of quality and waste of time. Meanwhile, a study by Dyah and Rizal (2006) stated that nearly $60 \%$ of Malaysians intended to seek private primary care but $73.2 \%$ could not afford the cost. Therefore, the findings of the study revealed the strong influence of health awareness towards the intention of seeking private healthcare among Malaysians.

The second factor refers to the knowledge of the public sector officers on takaful as well as how it affects their intention to use medical takaful coverage. Past research by Rahman et al. (2008) was offered by the industry to fulfil the customers' needs in managing the risk which is in line with the shari'ah ways. The study examined the purchasing behavior and knowledge of Malaysian undergraduate students with regard to the differences between takaful and insurance products. In particular, the study emphasized the following four 
main factors that reflect how knowledge can affect customers' intention: services delivery, services provision reputation, electronic services, and convenience. The findings showed that undergraduate students have the intention to use insurance products because they perceived them to be better than the takaful products in all the aforementioned factors.

As previously mentioned, takaful products are different from conventional insurance. The knowledge of the differences of both products is important because it allows customers to compare the better alternative prior to opting for a protection policy. Research by Saif (2012) stated that around $80 \%$ of the existing customers changed to takaful when a Yemeni conventional insurance company introduced takaful products in 2008. However, it was also argued that the insurance sector realized the importance of takaful products in terms of attracting the intention of Yemeni customers and investors because the content and policy of takaful products are transparent compared to any non-shari'ah elements.

Furthermore, Aziz et al. (2011) conducted a research to study government servants based on four main explanatory variables, namely product knowledge, awareness, advertising, and benefit of the product. The results indicated that the variables have a significant influence on the intention of Malaysian government employees towards the level of acceptance of motor takaful products. Subsequently, this showed that knowledge about the products is important to influence customers' intention. Moreover, Sarwar and Qureshi (2013) stated that the lack of insurance knowledge is one of the major barriers in the intention of purchasing health and life insurance.

In the case of the present study, it is crucial to note that public sector officers may not be aware of their health condition due to their work pressure. As a result, they may suffer from an illness in the future without having the chance to take any prevention. A study by Ellis (1995) reported that occupational stress can be inferred from the problems faced by the employees or from environmental interaction. More importantly, it should be noted that the consequences of this stress may manifest in terms of health problems, emotional reactions and organizational outcomes.

Apart from that, another issue of health awareness is the reduction of healthcare subsidies for public sector officers. The Economist (2014) stated that healthcare subsidization by the government is no longer sustainable. According to the World Health Organization (WHO), the Malaysian government continues with the subsidy-rationalization program in order to reduce the overall government expenditure whereby an outlay as large as healthcare tends to look increasingly unsustainable (11 ${ }^{\text {th }}$ April 2014). In other words, the healthcare provision for public sector officers is in a precarious situation due to the reduction of subsidies by the government from year to year. Therefore, it will be unfortunate for the public sector officers in the future because they need to pay using their own money to receive healthcare services.

The present study focuses on three groups of public sector officers, namely the police, firefighters, and teachers due to their risky and uncertain 
job conditions. In this regard, the Organization for Economic Co-operation and Development (OECD) pointed out that some countries have repeatedly cut the fees for hospitals as well as the subsidies for medication and equipment (OECD, 2009). Moreover, it should be noted that cutting the subsidies will increase the cost of healthcare; hence, the advent of sophisticated treatment will burden the people in covering the rest of the medical cost (Eiji \& Jun, 2012). Therefore, it is important for the public sector officers to obtain sufficient knowledge about the healthcare services provided by the takaful industry such as the medical takaful to prevent themselves from bearing high medical costs due to any uncertainty in the future.

A search of the literature showed that previous studies focused more on customer intention to participate in takaful from various factors which included mass media, word of mouth, and subjective norms (Maizaitulaidawati et al., 2016; Farhat et al., 2019), attitude, subjective norm, and perceived behavior (Maizaitulaidawati \& Asmak, 2013), perception of takaful operators' performance (Haji Wahab, 2018), and customer beliefs (Bhatti \& Md Husin, 2019).

However, a limited number of available studies focused on the influence of health awareness and knowledge factors on customers' intention. Apart from that, the literature also showed that none of the studies focused on Medical takaful coverage, especially among public sector officers in Malaysia. Therefore, this paper attempted to examine the relationship between health awareness and knowledge towards the intention to choose medical takaful coverage among public sector officers in the northern region of Malaysia. Other than that, this paper also aimed to fill the gaps in understanding the concept of Medical Takaful as well as the factors that influence its demand.

The organization of this paper is as follows: Section 1 begins with a brief introduction of takaful, followed by Section 2 which presents the literature. Next, Section 3 provides the methodology of this research, while Section 4 details the results and discussion of the study. Finally, Section 5 focuses on the conclusion and limitations of the research.

\section{Literature Review}

\subsection{Health Awareness}

Health is described as the level of functional or metabolic efficiency of a living organism. In humans, health is the ability of individuals or communities to adapt and self-manage when they are faced with physical, mental, or social challenges (Huber et al., 2011). In 1948 the WHO constitution, defined health in a broader sense as a state of complete physical, mental and social well-being rather than merely the absence of disease or infirmity.

On another note, awareness can be defined in several ways. Kjeldskov and Skov (2004) defined awareness as the ability to adapt to the changing 
circumstances as well as respond according to the context of use. Meanwhile, Neaton et al. (1993) defined awareness as the knowledge of being hypertensive which is often obtained through a healthy worker. Gregory et al. (1996) described awareness as a factor that influences a healthy lifestyle, including the effect of publicity on diet-related health subjects. According to the study, Asians are described as individuals who are less likely to be aware of the importance of beneficial change in health awareness, especially with regard to the diet content provided by public health campaigns, media publicity and advertising program.

More importantly, this health awareness contributes to the intention of enrolling in medical takaful scheme. Zuriah and Rosylin (2008) mentioned that intention enables people to be aware of medical takaful in the attempt to compensate one another after sustaining an accidental loss. A person in distress or experiencing loss may not be brought about by animosity between humans which is usually observed during unexpected events such as natural death, health adversity, unemployment and sickness. A possible explanation for this matter may be because insurance in its essence is an important device created to solve many social obligations. Mohamed (2008) mentioned that the intention of takaful is to obligate funds to be distributed for the purpose of strengthening the health care system by aggressively targeting the poorest population and rural areas.

On another note, it should be understood that the general community health is imperative. A study by Piviki (2002) encouraged community participation in health planning which includes the effort to enhance community awareness on health issues as well as the opportunity to increase networking between health care service providers and community members. The study showed that health awareness influences the intention of the community to join and obtain incentive values from the health planning program. Naail and Norsham (2014) also highlighted that the awareness of shari'ah compliance product is important in Muslims' daily life. Moreover, this awareness may act as a response towards individuals' intention in preparing for unexpected events in future.

Nevertheless, a high number of individuals are still not taking any steps towards the preparation despite its importance. Drechsler and Jütting (2007) through WHO (2006) determined the urgent need for public health awareness as a sustainable tool for health financing in order to reduce the high amount of the out-of-pocket payments as well as the incidence of catastrophic health shocks in the developing world. On the contrary, studies by Fletcher and Hastings (1984), Kunreuther and Pauly (2005) and Oluyemi (1995) highlighted that budget constraint is one of the reasons that affect customers' intention to not participate in an insurance scheme. Overall, the public provided the reason that they are confronted with various expenses which leave them with no expendable income to pay for the insurance premium.

The literature discussed in this study has concluded that many disadvantages may occur due to the lack of awareness regarding the importance 
of practicing good health care. Referring to the public sector officers, the Berita Harian newspaper in 2012 showed the statement of the Ministry of Health where the increasing number in claims for takaful coverage was a result of the recent increase in the number of people who suffered from several diseases. Therefore, this study aimed to measure whether health awareness influences the intention of the public sector officers to participate in medical takaful coverage. Thus, the first hypothesis as follows:

Hypothesis 1: There is a significant relationship between health awareness and customers' intention in using medical takaful coverage among public sector officers in northern Malaysia.

\subsection{Knowledge}

Knowledge can be interpreted in several ways. Ackoff (1999) defines knowledge as conveying instructions and answering how-to questions. In addition, he describes knowledge as a combination of information and understanding with the aim of increasing efficiency. However, Brucks (1985) explains knowledge in the context of a product by defining it as customers' intention towards specific information which concerns the primary source of the product knowledge of a given product. Other than that, it also includes customers' experience with the actual product and advertisement with the aim of influencing the customer's decision to select a product (Rao \& Monroe, 1988). Furthermore, Burton et al. (2009) determine the consistent ranking of product knowledge as the most important factor that influences the intention of a customer with regard to their purchase behavior.

Nevertheless, Alnemer (2015) states that the lack of knowledge and intention about the basics and technicality of the products and services can lead to an obvious deficiency in the customer-motivated reasons to have insurance products and services. Regarding the level of knowledge, most researches seem to agree that customers with a higher level of education tend to have higher intention to own insurance coverage (Beck \& Webb, 2003; Browne \& Kim, 1993; Li et al., 2007). More importantly, empirical evidence reveals that knowledge of conventional and Islamic finance is higher for the highly educated customer (Bley \& Kuehn, 2004).

A considerable number of studies indicates that the intention to purchase is slightly affected by knowledge (Yin et al., 2010). Jeddi and Zaiem (2010) found that the level of knowledge provides some impact on customers' intention. Hence, it can be concluded that a high level of knowledge is related to the ability to understand the benefits of risk management and long-term saving. Consequently, this leads to high precision in risk assessments that are positively correlated to the intention to demand any product (Beck \& Webb, 2003; Lo et al., 2011; Sherrick et al., 2004). 
On a similar note, other researchers have also highlighted the importance of knowledge. Hamid and Othman (2009) emphasized that the level of knowledge and understanding among Muslims in Malaysia may contribute to enhancing the intention of customers to purchase takaful products. Furthermore, Naail and Norsham (2014) mentioned that customers' buying intention is based on knowledge of takaful that can be obtained through reading, the Internet, and promotions given by takaful agents. A study by Lin and Chen (2006) indicated that customers are easily influenced by the product and service knowledge during the buying intention and buying decision. Accordingly, the study implied that customers' purchase intention and purchase decision under different product involvement tend to have a positive effect on product knowledge.

Moreover, a study by Sharif et al. (2011) revealed that about $47 \%$ of the respondents wished to know more about takaful terms, followed by $26.9 \%$ of the respondents who aimed to know more about the claiming process, $21.6 \%$ about the product, and $1.5 \%$ about related information. Hence, knowledge of takaful is important for customers because it can affect their buying intention. Accordingly, it is crucial to gain relevant insights into the buyer decision process or strategies in buying because it is one of the useful factors in understanding consumer behaviour. In most cases, consumers usually build a certain set of cognition or pieces of information and knowledge about the product offering prior to deciding whether to buy or not to buy the product. In other words, the lack of knowledge on takaful may affect customers' intention and decision to either buy the product or not.

Therefore, Ghazali et al. (2011) and Ahmad et al. (2010) stressed that the poor knowledge and understanding of insurance and takaful products in Malaysia, further affect customers' intention to use the services. Consequently, the present study aimed to investigate the effect of knowledge on customers' intention among public sector officers. Thus, the second hypothesis is as follows:

Hypothesis 2: There is a significant relationship between knowledge and customers' intention in using medical takaful coverage among public sector officers in northern Malaysia.

\subsection{Customers'Intention}

In the present time, the theory of reasoned action (TRA) model developed by Martin Fishbein and Icek Ajzen in 1975 has been widely and frequently used by classic persuasion models in psychology for the purpose of understanding the relationship between behavior, attitude, intention and belief within human action (Md-Taib et al., 2008). Moreover, Gillmore et al. (2002) explained that this theory has been used to predict and create an assumption on how individuals behave based on their pre-existing attitudes and behavioral intentions. In short, it can be understood that an individual will make the decision to do something if he or she has the intention to perform a certain behavior. 
On another note, several reasons have been identified as to why this model was adopted by previous studies. First, the TRA model is useful in determining or predicting individual intention. Apart from that, this theory is also flexible and can be easily adjusted in different contexts of research fields. Moreover, this fact is supported by published studies that investigated Islamic credit coverage (Muhammad Ali et al., 2017; Hanudin Amin, 2013), Islamic bank adoption (Sulaiman et al., 2016), and zakah (Islamic tax) compliance (Ram \& Roszaini, 2014). Therefore, this study chose to adopt this model for the purpose of predicting the behavioral intention to use medical takaful coverage.

Data from published studies have shown that there is a positive and significant relationship between health awareness and customers' intention. Moreover, this statement is supported by various studies including research by Montano et al. (1997) who demonstrated that health awareness is positively correlated to intention, while Elmanan (2005) found that health treatment has a positive correlation with customers' intention. Therefore, those who are aware of health takaful are likely to have a high intention to get takaful coverage (Zuriah \& Rosylin, 2008). Furthermore, Piviki (2002) stated that health planning is an effort to instil health awareness which is positively correlated to customers' intention.

A number of past studies found a significant positive relationship between knowledge and customers' intention. This statement is consistent with previous research by Burton et al. (2009) who found that product knowledge is correlated to the intention of customer purchasing behaviour. Meanwhile, Alnemer (2015) identified that a lack of knowledge has a positive correlation with intention because the customers are reluctant to participate in insurance products and services. In addition, Dettmann and Dimitri (2007) reported that there is a positive association between the level of education and intention in regard to customers' interest. More importantly, a study by Hamid and Othman (2009) managed to find a positive statistical relationship between knowledge and intention to purchase takaful products and services. Therefore, based on the evidence above, the current research adopted the theory of reasoned action (TRA) to determine customers' intention. Thus, the third hypothesis is as follows:

Hypothesis 3: There is a significant influence between health awareness, knowledge and customers' intention in using medical takaful coverage among public sector officers in northern Malaysia.

\section{Methodology}

\subsection{Theoretical Framework}

Figure 1 shows the theoretical framework of the present study as well as the variables that need to be examined according to the objective of the study. 


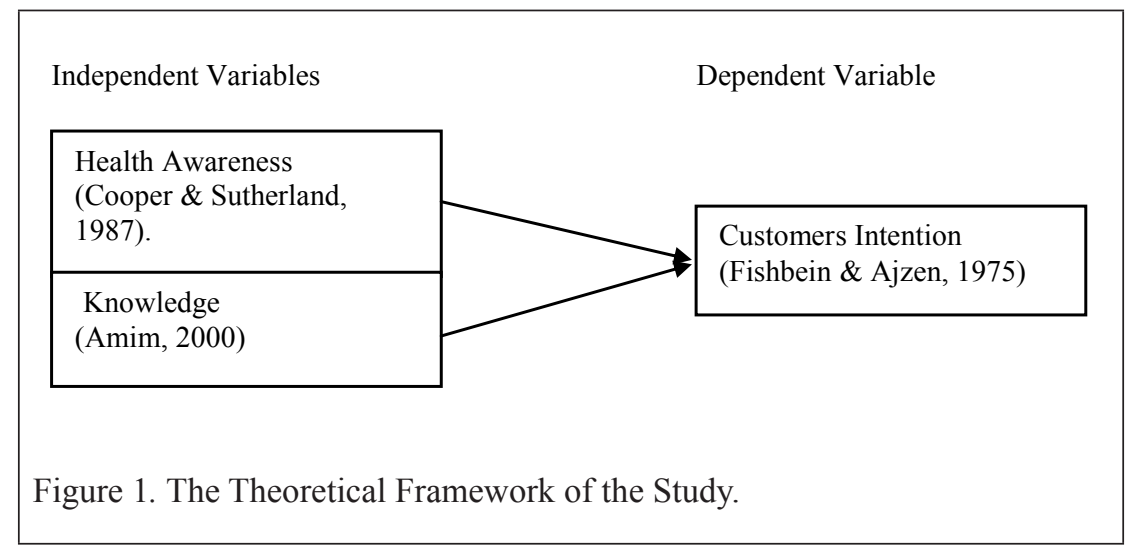

\subsection{Instrument and Measurement Items}

The present study adopted a survey-based questionnaire which consisted of 20 questions, including the demographic questions that were designed to answer the proposed hypothesis: the factors that affect customers' intention to use medical takaful coverage among public sector officers in northern Malaysia. The questionnaire was further divided into three parts but excluded demography. Moreover, it should be noted that all items intended to measure the constructs in the present study were adopted the previously validated instruments. First, Cooper and Sutherland's (1987) questions were adapted to test health awareness, followed by the second part from Amim (2000) which was compiled and added to the questionnaire in order to test knowledge. The third part was adopted from Fishbein and Ajzen (1975) in order to test customers' intention to use medical takaful coverage. More importantly, some of the items were modified to suit the target respondents. The questionnaires employed a six-point Likert scale from 'extremely disagree' to 'extremely agree' for data collection purposes.

\subsection{Sample}

The population was drawn using the disproportionate stratified random sampling from three public sector officers in northern Malaysia, namely the Royal Malaysia Police Department, the Fire and Rescue Department, and the State Education Department. Overall, there were 7,304 officers from the three government agencies. Following the suggestion of Krejcie and Morgan (1970), 367 officers were selected as the sample size for the present study (as cited in Sekaran \& Bougie, 2012). The allocation of the distributed questionnaires was as follows: 300 questionnaires for teachers, 40 for policemen, and 27 for firefighters. However, only 313 questionnaires were returned and valid for data analysis. The high response rate was attributed to the presence of the researcher at the organisations in ensuring the completeness of the questionnaires. 


\subsection{Data Analysis}

This study used descriptive and inferential analyses. Moreover, several statistical tools and methods were used from the SPSS software version 22.0 for the purpose of data analysis and hypothesis testing. The data analysis included pilot test, descriptive statistic, Pearson correlation, and multiple regression analysis.

\subsection{Pilot Test}

A total of fifty pre-respondents from the public sector officers were selected to participate in the pilot test prior to the distribution of the final questionnaire. The purpose of the pilot test is to ensure the clarity of the questionnaire's statements to the respondents as well as to detect other possible weaknesses in the questionnaire. Therefore, the pilot study was aimed to provide some feedback that could help the researcher to improve the questionnaire. In particular, some of the improvements involved the restructuring of the statements in simpler words in order to ensure the ease of comprehension. More importantly, the pilot test was also used to examine the question flow as well as to determine whether or not to remove or improve several questions prior to the large-scale implementation. Moreover, this idea is supported by Bryman and Bell (2007) who stated that it could assist in obtaining extra information and accurate responses from the respondents.

Table 1. Reliability Test

\begin{tabular}{lcc}
\hline \multicolumn{1}{c}{ Variable } & No. of Items & $\begin{array}{c}\text { Cronbach's Alpha } \\
\text { Pilot test }\end{array}$ \\
\hline Customers Intention & 5 & 0.977 \\
Health Awareness & 5 & 0.742 \\
Knowledge & 5 & 0.760 \\
\hline
\end{tabular}

Table 1 shows the result interpreted using the Cronbach's Alpha value obtained from the pilot test. The outcome obtained was in the range of 0.742 to 0.977 . According to Sekaran and Bougie (2010), the items are considered good if the value is in the range of 0.70 to 0.9 , while the items are considered excellent if the value is more than 0.90 . In the case of this study, the items were reliable to be tested since the value was more than $0.70(a>0.7)$.

\section{Results and Discussions}

\subsection{Respondent's Demographic Profile}

Frequency distribution was employed in the present study for the purpose of finding the frequency characteristics of the respondent profile. In the case of 
the current research, 367 questionnaires were distributed to the respondents. However, only 313 questionnaires were returned and valid for data analysis. Hence, demographic information such as gender, marital status, age, type of public sector and job category was obtained from the respondents. The demographic profile of the respondents for the present study is represented in Table 2 .

Table 2. Result of the Demographic Profile

\begin{tabular}{|c|c|c|c|}
\hline Demographic & Items & $\begin{array}{c}\text { No. of } \\
\text { Respondents }\end{array}$ & Percent \\
\hline \multirow{2}{*}{ Gender } & Male & 105 & 33.5 \\
\hline & Female & 208 & 66.5 \\
\hline \multirow{3}{*}{ Marital status } & Single & 47 & 15 \\
\hline & Married & 254 & 81.2 \\
\hline & Divorce & 12 & 3.8 \\
\hline \multirow{4}{*}{ Age } & Less than 25 years & 17 & 5.4 \\
\hline & $26-35$ years & 93 & 29.7 \\
\hline & $36-50$ years & 166 & 53 \\
\hline & 51 and above & 37 & 11.8 \\
\hline \multirow{3}{*}{$\begin{array}{c}\text { Type of public sector } \\
\text { officers }\end{array}$} & Teachers & 252 & 80.5 \\
\hline & Fire fighters & 23 & 7.3 \\
\hline & Police & 38 & 12.1 \\
\hline \multirow[t]{2}{*}{ Job category } & $\begin{array}{l}\text { Professional and } \\
\text { managerial }\end{array}$ & 241 & 77 \\
\hline & Supportive groups & 72 & 23 \\
\hline
\end{tabular}

The majority of the respondents in the study were female with a total of 208 respondents $(66.5 \%)$, whereas the remaining 33.5\% represented 105 male respondents. Regarding the marital status, 47 respondents $(15.0 \%)$ were single, 254 respondents $(81.2 \%)$ were married, and 12 respondents $(3.8 \%)$ were divorced. Meanwhile, most respondents were between the ages of 36 and 50 years old (166 respondents or 53.0\%), followed by 93 respondents $(29.7 \%)$ in the age range of 26 and 35 years old, 37 respondents $(11.8 \%)$ who were above 51 years old, and only 17 respondents $(5.4 \%)$ were younger than 25 years old. Table II also shows the type of public sector officers as follows: 252 respondents $(80.5 \%)$ were teachers, 38 respondents $(12.1 \%)$ were police, and 23 respondents $(7.3 \%)$ were fire fighters. Finally, it should be noted that 241 respondents $(77.0 \%)$ were from professional and managerial groups, while the remaining 72 respondents $(23.0 \%)$ were from supportive groups. 


\subsection{Relationship between Customers'Intention and Its Determinants}

The Pearson correlation analysis was utilised in the study for the purpose of determining the relationship between health awareness and knowledge with regard to customers' intention to use medical takaful coverage among public sector officers. Table 3 illustrates a significant positive relationship $(r=0.256)$ between health awareness and customers' intention to use medical takaful coverage. Therefore, hypothesis 1 is accepted.

Table 3. Correlation between Health Awareness and Customers' Intention

\begin{tabular}{lc}
\hline \multicolumn{2}{c}{ Correlations } \\
\hline \multicolumn{2}{c}{ Customers Intention } \\
\hline Health Awareness & $.256^{* *}$ \\
\hline ** Correlation is significant at the 0.01 level (2-tailed). &
\end{tabular}

Table 4 shows that there is a significant positive relationship $(r=0.151)$ between knowledge and customers' intention to use medical takaful coverage. Therefore, hypothesis 2 is accepted.

Table 4. Correlation between Knowledge and Customer's Intention

\begin{tabular}{cc}
\hline \multicolumn{2}{c}{ Correlations } \\
\hline Knowledge & Customers Intention \\
\hline ** Correlation is significant at the 0.01 level (2-tailed). & $.151^{* *}$ \\
\hline
\end{tabular}

\subsection{The Influence of Determinants on Customers' Intention}

Multiple regression analysis was conducted to determine the significant influence of health awareness and knowledge on customers' intention to use medical takaful coverage.

The result indicated that the $\mathrm{R}^{2}$ value was 0.069 or $6.9 \%$. Hence, the present study indicated that $6.9 \%$ of the variance in customers' intention to use medical takaful coverage was significantly explained by the two independent variables of the study, namely health awareness and knowledge. On the other hand, $93 \%$ of the variance was explained by other untested factors.

Moreover, the unstandardized $\beta$-coefficient for health awareness had a significant value of 0.302 , while knowledge it was 0.062 with a significant value of 0.280 . Therefore, it is clear that only health awareness significantly influenced customers' intention to use medical takaful coverage, whereas the knowledge variable was insignificant due to the value exceeding 0.05 . Therefore, hypothesis 3 is rejected. 
Table 5. Multiple Regression Analysis of the Coefficient

\begin{tabular}{ccccccc}
\hline & \multicolumn{2}{c}{$\begin{array}{c}\text { Unstandardized } \\
\text { Coefficients }\end{array}$} & $\begin{array}{c}\text { Standardized } \\
\text { Coefficients }\end{array}$ & & \\
\cline { 2 - 4 } & B & Std. Error & Beta & & Sig. \\
(Constant) & 2.836 & 0.308 & & & \\
Health awareness & 0.302 & 0.077 & 0.214 & 0.000 \\
Knowledge & 0.062 & 0.058 & 0.064 & & 1.082 & 0.280 \\
\hline
\end{tabular}

Dependent Variable $=$ Customers Intention

$\mathrm{R}^{2}=0.069, \mathrm{~F}-$ value $=11.512$, Significant $=0.000$

The following equation represents the multiple regression analysis:

$$
\gamma=\alpha+\beta 1 X 1+\beta 2 X 2
$$

where $\quad \gamma=$ Intention to use Medical Takaful coverage

$$
\begin{aligned}
& \alpha=\text { Intercepts (constant value) } \\
& \beta=\text { Unstandardized beta coefficient } \\
& \mathrm{X} 1=\text { Health Awareness (HA) } \\
& \mathrm{X} 2=\text { Knowledge }(\mathrm{KN})
\end{aligned}
$$

Therefore, the equation for the multiple regression analysis is shown below:

$$
\gamma=2.836+0.302 \mathrm{HA}+0.062 \mathrm{KN}
$$

The formula above explains that customers' intention to use medical takaful coverage will increase by 0.302 units when one unit of health awareness is increased. Meanwhile, an increase of one unit of knowledge reflects an increase in customers' intention to use medical takaful coverage by 0.062 units.

\subsection{Discussion}

Several published studies by Tsai et al. (2013), Jayawardhena et al. (2009), Munnukka (2007), and Porter and Donthu (2006) found that the sociodemographic variables which include age, education, gender, and others can influence the intention of consumers when making decisions. Moreover, many researchers considered gender and age as important factors that affect customers' intention (Zhang, 2005; Riquelme \& Rios, 2010; Jun et al., 2008; Dewan et al., 2009; Singh, 2014). Meanwhile, a study by Maizaitulaidawati and Asmak (2013) revealed that demographic variables are crucial in determining customers' intention to participate in a family takaful scheme. 
Accordingly, the demographic analysis showed that most of the public sector officers who participated as respondents in the present study were mature people (36-50 years old). Moreover, another large segment of the customers was in the age range of 26 to 35 years old (young people). Furthermore, the results revealed that the majority of the respondents possessed professional and managerial positions (241 respondents). Therefore, it is more relevant for takaful operators to provide diverse and unique medical takaful schemes that suit the preference and satisfaction of both groups. In other words, takaful operators ought to consider tailoring their products and services to suit the characteristics of the customers.

The outcomes revealed that there was a significant positive relationship among all the independent variables (health awareness and knowledge) and the dependent variable (customers' intention). In the case of the present study, the positive value $(r=0.256)$ signified a weak relationship between health awareness and customers' intention. The result is in line with previous studies which stated that health awareness has a positive relationship with customers' intention (Montano et al., 1997; Elmanan, 2005; Zuriah \& Rosylin, 2008; Piviki, 2002).

Similarly, the present study revealed a positive relationship between knowledge and customers' intention with a value of 0.007 ( $p<0.01$, Sig.2tailed). The value $(\mathrm{r}=0.151)$ signified a weak relationship between knowledge and customers' intention. Moreover, the result is consistent with prior research (Dettmann \& Dimitri, 2007; Burton et al., 2009; Hamid \& Othman, 2009; Alnemer, 2015).

Regarding the last objective, the result indicated that only health awareness significantly influenced customers' intention. However, knowledge had no significant influence because the value of 0.280 exceeded the significant value of 0.05 . Apart from that, the result showed the $\beta$-value of health awareness was 0.302 , while for knowledge it was 0.062 . Hence, it can be concluded that health awareness provides the strongest impact on the dependent variable as well as influences customers' intention to use medical takaful coverage among public sector officers in the northern region of Malaysia. More importantly, all the measured items can be used to evaluate the practice of relationship marketing, particularly for the takaful industry.

\section{Implication, Limitation and Conclusion}

\subsection{Implication}

The results of the present study have provided a number of useful implications for certain groups. On behalf of the takaful industry, this study acknowledged the important need for takaful operators, marketing teams, staffs, and agents to improve their performance by increasing their efficiency, creativity, innovation, and knowledge of product features in developing a good impression among potential customers. Hence, the findings of the present study are hoped to be useful by allowing the marketing teams to formulate marketing strategies. 
The results offered several significant methods that can be adopted to pique the intention of potential customers towards the medical takaful coverage facility. First, takaful operators should keep afloat customers' needs and preferences to ensure a creative and innovative marketing strategy. More importantly, this will help the customers to have more awareness of takaful products, especially medical takaful coverage. Accordingly, a survey should be carried out in real-time because the need to wait for a long period of time may limit the precision and usefulness of the information in the decision-making process. Therefore, comparisons should be made amidst the fast adaptation of marketing strategies.

Second, it is very important for takaful operators to educate their staffs and agents in ensuring that they have a good understanding of the product features. In other words, it is necessary to enhance staff knowledge for the purpose of providing a clear picture of the takaful product to potential customers. Moreover, the knowledge is aimed to attract potential customers who are concerned about the necessity of the medical takaful coverage scheme. Accordingly, it is highly suggested that public sector officers have adequate education and awareness regarding the importance of applying for medical takaful coverage for their health. Overall, this is to ensure that the customers are covered from unfortunate events. Meanwhile, promotional tools can be a useful approach to explain the benefits of medical takaful coverage products, which is likely to result in greater intention among potential customers.

Regarding the enhancement of knowledge and expertise among takaful staffs and agents, a series of seminars and workshops should be held to discuss the current knowledge related to principles, practices and product features for the purpose of building competence. On the other hand, the seminars are expected to provide good opportunities for senior managers to improve the concepts and principles of takaful. Meanwhile, workshops are believed to be helpful to officers who are directly involved with the structuring and transactions of takaful products because they are expected to further develop their competence and expertise.

The results of this study have provided a great amount of useful information to the public sector institutions. More importantly, the findings emphasised the need to increase the intention to use medical takaful coverage among public sector officers. In addition, forums and conferences are important avenues to create health awareness, knowledge and intention to participate in takaful protection. Therefore, it is important to ensure that the officers are always in good health to enable them to receive productive and efficient services.

Previous theory and literature related to health awareness, knowledge and customers' intention have proven suitable to be adopted even in the takaful industry research. The present study further contributes to the takaful industry field by further investigating the possibility of a relationship between health awareness and knowledge among public sector officers in regard to their intention to use takaful protection, especially the medical takaful coverage. Accordingly, the current research successfully expanded the existing knowledge of takaful products and services in Malaysia and other countries. 


\subsection{Limitation}

There are some limitations in this study. First, the location and the target respondents were limited because this study only focused on three public sectors in the northern region of Malaysia. Hence, it is recommended for future research to further investigate various types of public sectors and locations in order to obtain a wide range of responses.

Second, the sample size of the present study is considered small. In terms of directions for future research, further work could increase the sample size by including other segments such as private sectors to obtain a different view on customers' intention.

Third, the present study only focused on the factors of health awareness and knowledge towards customers' intention. Therefore, another possible area of future research would be to include other factors that influence customers' intention.

\section{Conclusions}

The present study aimed to achieve three main objectives. First, the current research attempted to identify the significant relationship between health awareness and customers' intention. The results illustrate a significant positive relationship between both factors. Next, the second objective was to examine the significant relationship between knowledge and customer intention. The results revealed that both independent variables, namely health awareness and knowledge had significant positive relationships with the dependent variable (customers' intention). Finally, the third objective was to determine the significance of health awareness, knowledge and customers' intention in using medical takaful coverage. The findings revealed that only health awareness significantly influenced the customers' intention of public sector officers in northern Malaysia.

\section{References}

Abubakar U. Farouk, Kamil Md Idris \& Ram Al Jaffri Saad. (2017). Determinants of attitude towards zakat on employment income in Nigeria, The International Journal of Banking and Finance, 13(1), 29-48.

Ackoff, R. L. (1999). Ackoff's Best. John Wiley \& Sons.

Ahmad, M. I., Masood, T., \& Khan, M. S. (2010) Problems and prospects of Islamic banking: A case study of takaful, MPRA Paper.

Ajzen, I. (1991). The theory of planned behavior: Organizational behaviour and human decision processes, 50, 179-211. 
Alnemer, H. (2015). Participants' perceptions about takaful operators disclosures system: An empirical study on saudi arabia. Islamic Finance, Performance and Efficiency. V (3). Gerlach Press. Germany.

Amim, M. O. (2000). Factors influencing the perception of government servantstowards takaful as an alternative to conventional insurance. Thesis (M.o.M). International Islamic University Malaysia (IIUM). Gombak.Selangor.

Aziz, W. A. B. W. A, Mat, A. B. C., \& Zin, E. A. M. E. W. (2011). A study of contributing factors in Islamic motor insurance. Gaziantep University Journal of Social Science. Vol. 10 No. 1, pp. 1-20.

Beck, T., \& Webb, I. (2003). Economic, demographic and institutional determinants of life insurance consumption across countries. The World Bank Economic Review, Vol. 17, No. 1, pp. 51-88.

Benjamin, N. W. J., Fong L. H., Goon L. T., Tan X. Y., \& Tan Y. C. (2014). The determinants on health and life insurance demand among Malaysians. Faculty of Business and Finance, Department of Finance. Universiti Tunku Abdul Rahman.

Berita Harian (BH) Online. Insurans RM1 b. Retrieved from:www. takafulinsurance.com.my/wp-content/uploads/2012/06/beritaharianinsurans1-billion.jpg

Bhatti, T., \& Md Husin, M. (2019). An investigation of the effect of customer beliefs on the intention to participates in family takaful schemes, Journal of Islamic Marketing.

Bley, J., \& Kuehn, K. (2004). Conventional versus Islamic finance: Student knowledge and perception in the United Arab Emirates. International Journal of Islamic Financia in Services, 5, 17-30.

Browne, M. J., \& Kim, K. (1993). An international analysis of life insurance demand. Journal of Risk and Insurance, 60, 616-634.

Brucks, M. (1985). The effect of product class knowledge on information search behavior. Journal of Consumer Research, 12(1), 1-16.

Bryman, A., \& Bell, E. (2007). Business research method (2 $2^{\text {nd }}$ ed.). Oxford University Press Inc.

Burton, S. E., Howlett \& Tangari, A. H. (2009). Food for thought: How will the nutrition labeling of quick service restaurant menu items influence consumers' product evaluations, purchase intentions, and choices?. Journal of Retailing, 85(3), 258-273.

Colman, A. (2015). Theory of reasoned action. A Dictionary of Psychology.

Cooper, C. L., \& Sutherland, V. J. (1987). Job stress, mental health, and accidents among offshore workers in the oil and gas extraction industries. Journal of Occupational Medicine, 29, 119-125.

Dettmann, R., \& Dimitri, C. (2007). Who's buying organic vegetables? Demographic characteristics of US consumers. Journal of Food Distribution Research, 49-62.

Dewan, S., Low, G., \& Land, L. (2009). Consumer choice model of mobile banking. Proceedings of the 20th Australasian Conference on Information Systems, PAPER NO. 101, Monash University, Melbourne, 2-4 December. 
Drechsler, D., \& Jütting, J. (2007). Different countries, different needs: The role of private health insurance in developing countries. Journal of Health Politics, Policy and Law, 32(3), 497-534.

Dyah, P. S., \& Rizal, A. M. (2006). Patients' satisfaction in antenatal clinic Hospital Universiti Kebangsaan Malaysia. Jurnal Kesihatan Masyarakat (Malaysia), 12(1), 09-18.

Eiji, T., \& Jun, K. (2012). The roles of public and private insurance for the health care reform of Japan. Hitotsubashi University, National Institute of Population and Social Security Research, Tokyo. Policy Research Institute, Ministry of Finance, Japan, Public Policy Review, 8(2), July 2012.

Ellis, K. (1995). The organizational approach to stress management. Psychological health in the workplace: Understanding and managing occupational stress. P Cotton (Ed.) Australian Psychological Society, 1995.

Elmanan, N. A. (2005). Evaluation of contribution rate in health insurance system Khartoum State", Faculty of Economic and Social Studies. Department of Econometrics. University of Khartoum. Khartoum.

Farhat, K., Aslam, W., \& Sany Sanuri, B. (2019). Predicting the intention of generation $\mathrm{M}$ to choose family takaful and the role of halal certification. Journal of Islamic Marketing.

Fishbein, M., \& Ajzen, I. (1975). Belief, attitude, intention and behavior: An introduction to theory and research. Addison-Wesley, Reading, MA.

Fletcher, K. P., \& Hastings, W. J. (1984). Consumer choice: A study of insurance buying intention, attitudes and beliefs. The Service Industries Journal, 4(2), 174-188.

Ghazali, P. L. B., Mohd, I. B., Mamat, M. B., \& Ahmad, W. M. A. W. (2011). Mathematical modelling in family takaful. Journal of Applied Science, 11(19), 3381-3388.

Gillmore, R. M., Matthew A., Morrison, D., Wilsdon, A., Elizabeth, W., Hoppe, M., Nahom, D., Murowchick, E. (2002). Teen sexual behavior: Applicability of the Theory of Reasoned Action. Journal of Marriage and Family, 64(4), 885-897.

Gregory, Y. H. L., Chris, L., Maria, Mc C., Ifran., M. \& Gareth, B. (1996). Ethnic differences in public health awareness, health perceptions and physical exercise: Implications for heart disease prevention. Ethnicity \& Health, 1(1), 47-53.

Haji Wahab, M. (2018). Perception of the takaful operators' performance towards customers' intention in using medical takaful card among public sector. Journal of Islamic Marketing, 9(3), 527-543.

Hamid, M. A., \& Rahman, N. M. N. A. (2011). Commitment and performance: A case of Takaful (Islamic Insurance) representatives in Malaysia. Australian Journal of Basic and Applied Sciences, 5(10), 777-785.

Hamid, M. A., \& Othman, M. S. (2009). A study on the level of knowledge and understanding among Muslims towards the concepts, Arabic and 
Shariah terms in Islamic Insurance (takaful). European Journal of Social Sciences, 10(3), 468-478.

Hanudin Amin.(2013). Factors influencing Malaysian bank customers to choose Islamic credit coverage: Empirical evidence from the TRA model.Journal of Islamic Marketing, 4(3), 245-263.

Huber M, Knottnerus JA, Green L, Horst H, Jadad AR, Kromhout D et al. (2011). How should we define health?. BMJ 2011;343: d4163.

Jayawardhena, C., Kuckertz, A., Karjaluoto, H., \& Kautonen, T. (2009). Antecedents to permission based mobile marketing: An initial examination. European Journal of Marketing, 43(3/4), 473-499.

Jeddi, N., \& Zaiem, I. (2010). The impact of label perception on the consumer's purchase intention: An application on food products. IBIMA Business Review, 1-14.

Jun, B., Pil, K., Jae, W., \& Byung, G. (2008). Adoption of on-line banking service considering the moderate effects of on-line banking service type. Proceedings of the 2008 Second International Conference on Future Generation Communication and Networking Symposia, 77-80.

Kjeldskov, J., \& Skov, M. (2004). Supporting work activities in healthcare by mobile electronic patient records. In Proceedings of the 6th Asia Pacific Conference on Human Computer Interaction, APCHI 2004, Rotorva, New Zealand, 2004.

Krejcie, R. V., \& Morgan, D. W. (1970). Determining sample size for research activities. Educational and Psychological Measurement, 30, 607-610.

Kumanyika, S. K., Van Horn, L., Bowen, D., Perri, M. G., Rolls, B. J., Czajkowski, S. M., et al. (2000). Maintenance of dietary behavior change. Health Psychology, 19(Suppl. 1), 42-56.

Kunreuther, H. \& Pauly, M. (2005). Insurance decision-making and market behavior. Foundations and Trends in Microeconomics, 1(2), 63-127.

Li, D., Moshirian, F., Nguyen, P., \& Wee, T. (2007). The demand for life insurance in OECD countries. The Journal of Risk and Insurance, 74(3), 637-652.

Lin \& Chen. (2006). The influence of the country-of-origin image, product knowledge and product involvement on consumer purchase decisions: An empirical study of insurance and catering services in Taiwan. Journal of Consumer Marketing, 23(5), 248-265.

Lo, A. S., Cheung, C., \& Law, R. (2011). Hong Kong residents' adoption of risk reduction strategies in leisure travel. Journal of Travel and Tourism Marketing, 28, 240-260.

Md-Taib, F. M., Ramayah, T., \& Abdul-Razak, D. (2008), Factor influencing intention to use diminishing partnership home financing, International Journal of Islamic and Middle Eastern Finance and Management, 1(3), 235-248.

Maizaitulaidawati Md Husin., \& Asmak Ab Rahman (2013). What drives consumers to participate into family takaful schemes? A literature review. Journal of Islamic Marketing, 4(3), 264-280.

Maizaitulaidawati Md Husin., Noraini Ismail., \& Asmak Ab Rahman (2016). The roles of mass media, word of mouth and subjective norm in family 
takaful purchase intention. Journal of Islamic Marketing, 7(1), 59- 73, https://doi.org/10.1108/JIMA03-2015-0020

Marhanum, C., Nurdianawati, I. A., \& S. Salwani, R. (2013). Measuring takaful agents' understanding towards the objectives and concepts of takaful. Journal of Islamic Finance, 2(1), 020-030. IIUM Institute of Islamic Banking and Finance.

Mohamed, G. K. (2008). Financing health care in Sudan: Is it a time for the abolishing of user charges?. Sudanese Journal of Public Health, 2(1), $38-47$.

Montano, D. E., Thompson, B., Victoria, M. T., \& Janice, M. (1997). Understanding mammography intention and utilization among women in an Inner City Public Hospital Clinic. University of Washington, Seattle, Washington. Preventive Medicine: 26, 817-824 (1997). Article No.: PM970215

Muhammad Ali., Syed Ali Raza., \& Chin-Hong Puah (2017). Factors affecting to select Islamic credit coverages in Pakistan: The TRA model. Journal of Islamic Marketing, 8(3), 330-344.

Munawar Iqbal. (2013). Islamic finance: An attractive new way of financial intermediation. The International Journal of Banking and Finance, $10(2), 1-24$.

Munnukka, J. (2007). Characteristics of early adopters in mobile communications markets. Marketing Intelligence \& Planning, 25(7), 719-731.

Naail, M. K., \& Norsham, M. N. (2014). Factors influencing the choice of takaful over conventional insurance: The case of Malaysia. Journal of Islamic Finance, 3(2), 001 - 014. IIUM Institute of Islamic Banking and Finance.

Neaton, J. D. et al. (1993). Treatment of mild hypertension study. Final results. JAMA 1993; 270, 713-724.

OECD. (2009). Economic survey of Japan 2009. OECD Publishing.

Oluyemi, S. A. (1995). Recent development in the Nigerian banking system and insured banks' assets portfolio behaviour: An empirical study, Nigerian Deposit Insurance Corporation (NDIC). Quarterly Review, 5(4), 32-44.

Piviki, J. R. (2002). Practical strategies for facilitating meaningful citizen involvement in health planning. Ottawa, Canada: University of Ottawa.

Porter, C. E., \& Donthu, N. (2006). Using the technology acceptance model to explain how attitudes determine internet usage: The role of perceived access barriers and demographics. Journal of Business Research, 59(9), pp. 999-1007.

Ram Al Jaffri Saad., \& Roszaini Haniffa. (2014). Determinants of zakah (Islamic tax) compliance behavior. Journal of Islamic Accounting and Business Research, 5(2), 182-193.

Rao, A. R., \& Monroe K. B. (1988). The moderating effect of prior knowledge on cue utilization in product evaluations. Journal of Consumer Research, 15 (September), 253-264.

Rahman, A., Ali, N., Che-Seman, A., \& Wan-Ahmad, W. M. (2008). Comparative study between auto takaful and auto insurance purchasing behaviour among Malaysian undergraduates. Jurnal Syariah, 16(1), 75-88. 
Riquelme, H. E., \& Rios, R. E. (2010). The moderating effect of gender in the adoption of mobile banking. The International Journal of Bank Marketing, 28(5), 328-341.

Saif, M. (2012). Islamic insurance: A competitive business in Yemen. Yemen Times News Letter 1545 ( $9^{\text {th }}$ February $)$. Retrieved on December 12, 2013, available online at: http://www.yementimes.com/en/1545/business/360/ Islamic insurance-a-competitive-business-in Yemen.htm.

Sarwar, A., \& Qureshi, H. A. (2013). Awareness and willingness to buy private health insurance and a look into its future prospects in Pakistan. European Journal of Business and Social Sciences (EJBSS), 2(1), 69-81.

Sekaran, U., Bougie, R. (2010). Research Method for business: A skill building approach $\left(4^{\text {th }} \mathrm{ed}\right.$.) New York, John and Sons Publication.

Sekaran, U., Bougie, R. (2012). Research method for business: A skill building approach $\left(5^{\text {th }} \mathrm{ed}\right)$. New York, John and Sons Publication.

Sharif, M. B., Hafizah, N. H. M., \& Jamil, M. A. A. (2011). Consumer perceptions on takaful business in Brunei Darussalam. International Conference on Management (ICM 2011) Proceeding, Sultan Sharif Ali Islamic University and Legal Advisor at Abrahams Davidson \& Co., Brunei.

Sherrick, B. J., Barry, P. J., Ellinger, P. N., \& Schnitkey, G. D. (2004). Factors influencing farmers' crop insurance decisions. American Journal of Agricultural Economics, Vol. 86, No. 1, pp. 103-114.

Singh, S. (2014). Customer perception of mobile banking: An empirical study in National Capital Region Delhi. Journal of Internet Banking and Commerce, 19(3), 2-23.

Sulaiman Lujja., Mustafa Omar Mohammad., \& Rusni Hassan. (2016). Modelling public behavioral intention to adopt Islamic banking in Uganda: The theory of reasoned action. International Journal of Islamic and Middle Eastern Finance and Management, 9(4), 583-600.

The Economist. (2014). How sustainable is Malaysian healthcare? Retrieved from: http://www.eiu.com/.

Tsai, C., Zhu, D., \& Jang, Y. (2013). A study on the consumer adoption behaviors of internet bank. Journal of Networks, 8(12), 2956-2963.

Webb, T. L., \& Sheeran, P. (2006). Does changing behavioral intentions engender behavioral change? A meta-analysis of the experimental evidence. Psychological Bulletin, 132, 249-268.

World Health Organization (WHO). (2006). World health report-Working together for health. Geneva: WHO.

Yin, S. W. L., Du, L., \& Chen, M. (2010). Consumers' purchase intention of organic food in China. Journal of the Science of Food and Agriculture, 90(8), 1361-1367.

Zhang, Y. (2005). Age, gender, and internet attitudes among employees in the business world. Computers in Human Behavior, 21(1), 1-10.

Zuriah, A. R., \& Rosylin, M. Y. (2008). Family takaful: Its role in social economic development and as a savings and investment instrument in Malaysia. Shari' a Journal, 16(1), 89-105, International Islamic University Malaysia (IIUM). Malaysia. 